\title{
Strategies to Improve Service Quality Through Digitalization of Banking Services at PT. Bank Negara Indonesia (Persero) Tbk
}

\author{
Rosnaini Daga*, Fadliyani Nawir, \& Dhita Pratiwi AR \\ Faculty of Economics and Business, Institut Bisnis dan Keuangan Nitro, Makassar, Indonesia
}

\begin{abstract}
The strategy of improving service quality through the digitalization of services is a strategy that a company uses to develop digitalbased services to answer consumers' increasingly digital needs. Likewise, the banking business continues to innovate to improve the quality of its services. The digitization of banking services is one strategy that can answer problems that occur in terms of improving the quality of banking services. PT. Bank Negara Indonesia Central Jakarta has implemented digitalization of services for the last 3 (three) years. It can be seen from the annual report and internal interviews that Bank Negara Indonesia has achieved good performance targets. However, several obstacles are faced in implementing the digitalization strategy for services such as legacy IT systems. This work culture is not yet digital and poor coordination between BNI's internal divisions. Some of these things need to be considered more seriously to achieve PT. Bank Negara Indonesia's vision and mission.
\end{abstract}

Keywords: Strategy; service quality; service digitalization.

\section{Introduction}

The banking industry plays an essential role in improving a country's economy because its economic activities are always related to banking activities. Current technological developments have led to the emergence of new industries in the payment and financing sector, which are also banks' businesses (Bartnik et al., 2018; Sung, 2021). Based on Law no. 10 of 1998 concerning Banking, Banks are business entities that collect funds from the public in the form of savings and distribute them to the people in the form of credit and other forms to improve the people's standard of living at large. In running its business, a bank has products and services for its customers to enjoy. Bank products and services have different characteristics depending on the issuing bank. The rapid development of technology has made people's lifestyles change from traditional patterns towards a more modern one by utilizing information technology, telecommunications, and the internet (Hassan \& Wood, 2020; Lo Liang kheng, 2010).

This is the current concern of banks, which must take advantage of technological developments to support effective and efficient banking activities. One of the innovations can be achieved by developing bank products and services through the digitization process. Digitalization is transferring media from printed form to electronic; BNI is one of the State-Owned Commercial Banks committed to transforming into a digital bank in line with the digital trend, which has become a vital force in the era of industrial revolution 4.0. The digitalization carried out by the BNI bank includes various digital products developed by BNI, namely: BNI M-banking, BNI Internet Banking, BNI UnikQu, BNI Digital Loan, BNI Agent, and so on. By digitizing, banks have made long-term investments in the future; thus, digital channels can save costs per transaction. A bank that is already digital provides convenience and comfort for its customers, will also attract many new customers who are currently in their productive age and relatively young.

Technological developments have not only affected the banking industry, but many financial technology companies have sprung up. Fintech offers convenience in financial transactions ranging from payment methods, fundraising, loans to asset management which can then be accelerated and shortened by using technology (Dodds et al., 1991;

\footnotetext{
* Corresponding author.

E-mail address: rosnaini.daga79@gmail.com (Rosnaini Daga)
} 
Mashur et al., 2019; Sondakh, 2015; Yoon C. Cho, 2015). The convenience provided by fintech is the focus for banks to continue to innovate, develop and improve service quality to fulfill customer desires and satisfaction, and maintain customer trust in the bank so that customers will be loyal to the bank (Al-Refaie, 2015; Bacile et al., 2018; Risal, 2019). In the current digitalization era, banks will implement fintech 4.0 as a medium to develop their business through technology. Based on the description that has been stated above, the formulation of the problems in this study are:

1. What strategies are used to improve service quality through the digitalization of banking services at PT. Bank Negara Indonesia (Persero) Tbk.?

2. What are the supporting and inhibiting factors in implementing the strategies used to improve service quality through digitizing banking services at PT. Bank Negara Indonesia (Persero) Tbk?

\section{Methodology}

The research method used in this research is descriptive research with qualitative analysis. Descriptive study is not intended to test specific hypotheses but describes "as is" about a variable symptom or condition. This research approach uses data collected in the form of words, pictures, and not numbers. This data can be obtained from interviews, field notes, and photos while carrying out field research to determine the strategies BNI uses to improve its services through the digitization process. Data collection techniques used in this research are literature study, field study, observation, interviews. A literature study is done by collecting data from books, lecture materials, literature and studying theories related to the issues (Suriyanti et al., 2020). Field studies are carried out by directly observing the object to be researched or surveying the BNI head office bank because this is done to obtain accurate and relevant data. Observations were made now on the item under study, in this case, the BNI head office bank. Interviews or interviews were carried out by asking directly about the subject matter of the discussion to the parties concerned to obtain the results and information data that would be questioned in this study.

\section{Results and Discussion}

\subsection{Analysis of Strategies for Improving Service Quality through Digitalization of Services at PT BNI (Persero) Tbk.}

\subsubsection{Development of Digital Banking Capabilities}

BNI's vision is to become a financial institution that excels in service and performance. BNI continues to make improvements through innovation to answer challenges and changes according to the latest developments. The design carried out is contained in developing 5 (five) digital banking capabilities: First, digital Branding and Proposition; this is done by creating personal customer-based services accompanied by providing information and products according to customer needs and designing thinking to validate requirements. It is deeper. Second, new Digital Channel, this effort is in the form of developing D-Brach as a physical channel by utilizing the use of smart kiosks, developing BNI digital banking applications based on Mobile Platforms, such as Yap! (QR-based payment feature with a global network), developing Chat Bot (Artificial Intelligent / AI that can serve messaging-based banking information. In this case, Thrid, Digital Business, and Ecosystem increase the penetration program for digital business solutions on several priority ecosystems, developing automation processes in a series of BNI operational processes. Fourth, agile IT, creating Two Speed IT Development (developing capability for acceleration and agility in the process of developing solutions, developing API Management (Application Programming Interface) which is the development of compatibility to potential digital ecosystems, such as marketplaces, smart cities, and others, as well as providing Big Data which is the development of behavioral analytic capabilities for delivering conceptual solutions to consumers. Fifth, digital Culture \& innovation are carried out by building a BNI Innovation Center to incubate digital business ideas and organize the BNI Business Innovation Award (Binnova) as competition for business ideas and innovation from internal BNI employees to spark a spirit of the invention.

\subsubsection{Digitalization of Services}

The development of information and digital technology such as the internet, cloud, big data, Internet of Things (IoT), and artificial intelligence (AI) has triggered changes in the industrial sector. This is an opportunity for BNI to improve service quality through appropriate strategies by utilizing existing technology by digitizing services to enhance service 
quality. Digitalization of services carried out by BNI in a strategy to enhance the quality of service is as follows:

(1) BNI Digital Account Opening (DOA) is digital business development in providing convenience and convenience for opening savings services anytime and anywhere. Opening a BNI digital account makes it easy to open a BNI savings account using a smartphone. The BNI digital account opening application has been accessed by 74,936 devices/gadgets, with 8,242 accounts opened through this application and Rp 11.09 billion.

(2) BNI SONIC (Self Service Opening Account) BNI SONIC services are handled by machines quickly and thoroughly and typically like opening savings at conventional outlets. Suppose BNI SONIC is placed in an outlet. In that case, the operating time is 8 hours or 480 minutes with an average account opening duration of 2 minutes 45 seconds or 3 minutes. The number of account opening is 160 more than the conventional beginning serving up to 32 accounts during bank operating hours. BNI Sonic has collected DPK of IDR 34.35 billion with a total of 13,191 accounts opened during the first year of its launch.

(3) CINTA is a chatbot developed by utilizing Artificial Intelligence technology and Machine Learning. Cinta uses the chat platform to provide Cinta's follower's services, especially BNI customers with the millennial segment. The value proposition offered is simple, personalize, familiar. CINTA is also equipped with capabilities that include program personalization, ATM-Locator, promos, banking education facilities for customers, and surveys \& coupons.

(4) Agen46 Services are classified as LKD (Digital Financial Services), Laku Pandai (Officeless Financial Services for Inclusive Finance), and e-payment systems. Currently, there are 157,144 Agen46 agents throughout Indonesia. The developed method can run on the web and mobile platforms and is also equipped with EDC Android for easy transactions.

(5) BNI Call Virtual Assistant is a virtual application for customers and non-customers based on conversational via text and voice for information and transaction needs to be accessed via mobile devices. The use of BNI Call Virtual Assitant as of December 2019 has reached 20\% of full inquiry activity services. The estimated telecommunication cost savings in the first year were 3 billion, and the estimated outsourcing costs were 4 billion in the first year.

(6) BNI Digital Service, an API-based digital capability that provides convenience, speed, security for the needs of BNI financial services that are integrated into all digital business ecosystems that are currently developing. Several entities connected to the BNI API Service include Startup \& Fintech, BUMN, Ministries, Universities, and retail. More than 150 B2B services have been linked to the BNI API.

(7) BNI Mobile Remittance, MoRe is a money transfer application where money transfers can be made via smartphones based on IOS and Android to be accessed anywhere and anytime. This application makes it easy for Indonesian Migrant Workers (PMI) who work in Singapore to send money to all banks in Indonesia easily, safely, quickly, and reliably.

(8) Society for Worldwide Interbank Financial Telecommunication-Global Payment Innovation or SWIFT GPI is a global cross-border payment innovation that BNI has implemented. By implementing the first SWIFT GPI in Indonesia, BNI will provide new experiences to customers in making international payments for business, education, and other needs in foreign exchange (forex) from Indonesia to all over the world easily, quickly, comfortably, and safely.

\subsubsection{Improvement of Service Quality}

BNI continues to make various innovations through digitalized services and focuses on increasingly complex customer needs to improve service quality. BNI's designs are a strategy to enhance service quality, supported by a passion and culture of serving customers at every touchpoint. Several techniques and updates that have become BNI's strategy to improve the quality of service include:

(1) Service campaign - beyond service, through the Month of Service program implemented in each regional office, BNI wishes to continue serving wholeheartedly and providing exciting and memorable experiences for every customer. day. This is a form of BNI's commitment to creating a culture of helping at every touchpoint 
through the best service, done without waiting for the customer's day. Through the role of all front liners in all BNI Branch Offices from Sabang to Merauke, BNI comes with services that are faster, easier, and more personalized. Impression and good service from the BNI frontline are crucial to creating customer satisfaction, leading to trust and loyalty. Loyal customers are strategic assets for companies that can provide added value in the long term. The month of service is one of BNI's annual program campaigns and momentum for BNI to position the company as a bank that is always present in customers' lives with features, conveniences, and various other value-added financial solutions.

(2) Service as a business accelerator, various programs, and innovations are carried out to promote service as a driving force for business. Service as Business Accelerator, a service that is oriented to customer needs and satisfaction and focuses on the function and role of services in creating sustainable business opportunities that impact the achievement of company revenues. Various programs and innovations have been carried out, namely: a) Fun Referral Program. This program aims to improve BNI outlets' performance in each Regional Office through synergy between BNI and its subsidiaries (BNI Life). This program is carried out to increase fee-based income through Frontliner officers' ability to provide solutions to customer needs in using insurance. b) Education Cash Management Program (E-Camp), in line with the Bank's Business Plan (RBB), BNI continues to make improvements to be able to grow the transactional banking business as an effort to increase non-interest income. E-Camp is one of the programs developed to improve Frontliner officers' competence as financial advisors who can explore needs and provide solutions to non-individual (institutional) customers in the management of financial transactions (cash management).

(3) Digital Service Innovations and updates made, namely: a) Smart Digital System (SDS) as one of BNI's strategic tools, has successfully implemented to support business processes and services at Branch Offices. Through SDS, it is easier and faster for service officers to personalize services according to customer expectations. b) BNI Orange Magz also supports BNI digital service's implementation process as an application to make it easier for customers to open accounts at Outlets / Branches by understanding product information and benefits through QR Code. c) E-Roleplay, which was developed to support the process of improving Frontliner employees' capabilities as one of the Service Quality Unit efforts to ensure that service quality standards at each BNI touchpoint are appropriately implemented.

\subsection{Supporting Factors and Inhibiting Factors in the Implementation of PT. BNI (Persero) Tbk.}

\subsubsection{Supporting Factors}

Implementing the digitalization strategy for BNI services requires supporting factors so that the strategy's objectives can be achieved according to the target. The several supporting factors are: (1) Commitment of the board of Directors to BNI continues to be committed to digitalization in its service sector; this is evidenced by the support from various ranks within the BNI organization, from directors to employees focusing on digitalization development. The addition of D-Brach BNI that occurs every year shows the board of directors' commitment to increasing the digitalization of existing BNI services. (2) The need for more digital customers, in the increasingly competitive banking industry competition in this digitization era where customer needs and desires are increasingly leading to speed and speed in transactions, BNI continues to develop its services towards digital, starting from developing various features to establishing a new strategic business to survive in the current era of disruption.

\subsubsection{Obstacle factor}

In the implementation of a digital service strategy, several inhibiting factors can affect the implementation process. Some of the inhibiting factors are as follows: (1) The legacy of the IT system, Information Technology, which is currently booming or loved by many people, forces banks in Indonesia to adapt to something new. BNI as a financial institution is required to adapt to the IT system and the IT system, which is something new for banks in Indonesia. This resulted in BNI moving from an old system (conventional) to a new system (digital). However, to move to a new system, it was still hampered by the old system that had not been able to open its mind to a better plan fully. (2) BNI Work Culture, digitalization of services is something new within the internal scope of BNI so that the work culture that exists within BNI is not optimal in terms of digitizing services. BNI's work culture is still in the transition stage 
from conventional to digital. Also, digitizing new services is carried out at the head office, regional offices, and several branch offices that have not been able to cover all branches in Indonesia. (3) Poor coordination between divisions, digitalization of services is not just a change from a conventional system to a digital strategy but is a very complicated matter that requires careful preparation from each internal BNI. Coordination between divisions at BNI cannot be said to be right; there is still a lack of readiness between divisions and also each unit that lacks understanding of digitalization. Lack of support between companies is also an obstacle to digitizing existing BNI services.

\subsection{Implementation of Digitalization of Service Services to Improve Service Quality at PT. BNI (Persero) Tbk.}

Digitalization of services is an innovation that was developed to respond to society's needs in the era of disruption that is currently growing in Indonesia. In the age of disruption, competition is getting tighter in providing services between financial institutions with startups whose development is increasing every day. BNI as a financial institution must prepare various strategies that can provide satisfaction in terms of customer service. BNI's plan for improving service quality by developing the digitalization of services. Digitalization of services aims to enhance the quality of service and also increase fee-based income for BNI. By digitizing services carried out by BNI, it will undoubtedly impact company reports in terms of improving service quality and increasing transactions through BNI e-channels. This dramatically affects the image of BNI as one of the digital banks in Indonesia. The better the development of digitalization of existing services at BNI, the better the public's interest in using BNI's services.
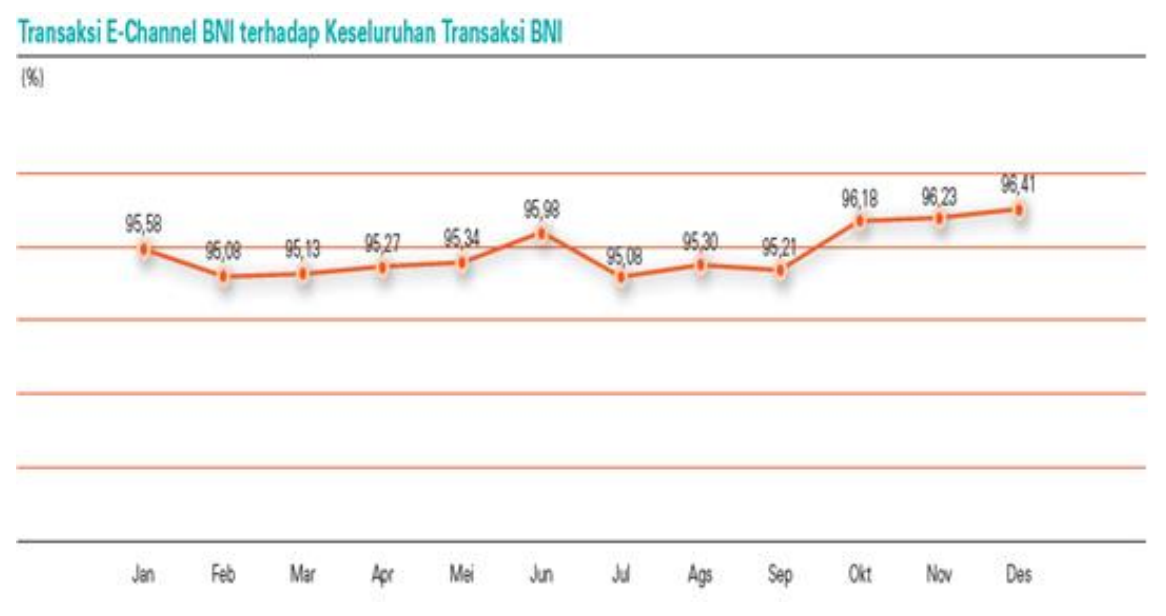

Fig. 1. BNI E-Channel Transaction Graph

Source: Annual Report PT. Bank Negara Indonesia (Persero) Tbk.

\subsubsection{SWOT Analysis Strategy}

After seeing the various strategies carried out by BNI and several inhibiting factors in the implementation of the digitalization strategy for BNI services, the author will first classify the different strengths, weaknesses, opportunities, and threats that will occur in the implementation and development of digitization of BNI services in the future.

(1) Strengths, in terms of the forces that BNI has in its strategy to improve service quality through the digitalization of services, we can see that BNI has a strong commitment to the development of digitalization of services by continuing to carry out the process of enhancing and developing the digitization of various business sectors. Also, the strength of BNI is the D-Branch which is spread in multiple big cities in Indonesia.

(2) Weakness, digitalization of services is an innovation in the banking world, so that it still has an obstacle or disadvantage that must require adaptation. In the development of digitalization of services, BNI still has barriers to transforming conventional systems into digital systems. BNI's work culture has not 
wholly entered the digitization system, and there is a lack of coordination between divisions within BNI itself.

(3) (Opportunities, digitalization that is currently booming in the community, and seeing the community's needs that are increasingly going digital can be an opportunity for BNI to continue to develop digitalization of services. BNI also has the opportunity to collaborate/collaborate with fintech companies and business startups for the development of a BNI service digitization strategy and can also take advantage of existing human resources by continuing to provide IT training and with various social media that can be used as promotional media for digitizing services available in BNI.

(4) Threats, the rapid development of information technology have led to the emergence of new crimes in the digital world, such as cybercrime, hacking, and malware/viruses. This is a threat to BNI in digitalization when it could disrupt the development process of digitalization of services at BNI. After the authors grouped the SWOT analysis sections one by one, then the authors will group again based on the correlation between the two parts, namely SO (how is the strength of the strategy for digitizing BNI services in the future with the opportunities available), ST (how is the strength of the process for digitizing BNI services in the future with the possible threats), WO (how can the weaknesses in the BNI service digitization strategy be overcome with the opportunities available) and the last one is WT (how the shortcomings in the BNI service digitization strategy can still be fixed with threats that exist). may occur in the future) as follows:

a) Strengths and Opportunities: Increasing cooperation with various Fintech companies and startups Business; Improve existing human resource knowledge with different IT training and skills; Improve IT systems to develop digitalization of services.

b) Strengths and Threats: Strengthening IT security systems; Be more able to determine the risks that can occur in digitizing BNI services; Maintaining trust and good relationships with BNI customers.

c) Weakness and Opportunities: Strengthening BNI's internal mindset towards developing digitalization of services by collaborating with Fintech companies; Use of social media in promoting the digitalization of BNI services; Improve coordination between divisions in BNI by implementing or copying existing systems in Fintech companies.

d) Weakness and Threats: a) Strengthening IT security systems; b) Creating Standard Operating Procedures (SOPs) that can mitigate the risk of digitizing BNI services; c) Increase BNI's internal capabilities in terms of preventing cybercrime.

\section{Literature Search Findings}

In his book, (Avramidis et al., 2020; Kang \& Shivdasani, 1995), a Bank, collects funds from the public in the form of deposits and distributes them back to the community in the form of credit and or other documents to improve the standard of living of the people at large. Meanwhile, the banking business includes three activities, namely raising funds, channeling funds, and providing other bank services. According to Pearce, the strategy is a company's plan, which reflects the company's awareness of when, where, and how to compete against opponents with specific goals and objectives. According to Morrisey, the strategy is a process to determine the company's direction to achieve all its missions. According to Scholes and Johnson, the system is the direction and scope of an organization or institution in the long term that aims to achieve profit through the configuration of resources in the environment to meet market needs. According to Halim A. strategy, namely how an organization or institution will accomplish a goal following the opportunities and threats of the external environment it faces and its internal capabilities and resources.

According to(Nurhilalia et al., 2019; Peteraf, 1993; Teece et al., 1997), three strategic foundations can help organizations gain a competitive advantage: cost advantage, differentiation, and focus. Cost advantage emphasizes manufacturing standardized products at low unit costs for consumers sensitive to price changes. Differentiation is a strategy to create products and provide services that are considered unique across industries and aimed at consumers who are relatively unconcerned about changing prices. Focus means making products and providing services that meet a small group of consumers (Chamidah et al., 2020; Londhe, 2014). SWOT analysis is a strategic planning 
technique that is useful for assessing the strengths and weaknesses, opportunities, and threats in a company, both in current and new planning. SWOT analysis has several main elements or elements, namely strengths, weaknesses, opportunities, and threats. Here are some of the aspects of a SWOT analysis, which are as follows: (1) Strength is one of the features used to analyze the strength of a company, for example, such as strength in terms of strategic position, product quality, the technology used, or other advantages that emphasize company excellence; (2) Weakness an element that is used to determine the weaknesses of a company. To find out, a company can compare its competitors; (3) Opportunity are one of the elements usually created at the beginning of starting a business. This is because a company is founded based on opportunities for winning; (4) Threats, are among the most essential elements to determine whether the business we make can survive or not in the future.

The development of information technology has led to an evolution that has led to digital banking services (digital banking). This service aims to improve operational activities' efficiency and the quality of bank services to its customers. For this reason, banks need to develop business strategies that lead to digital banking services. Digital banking services are banking services or activities using bank-owned electronic or digital means and/or through digital media owned by prospective customers and/or bank customers, carried out independently. This enables prospective customers or bank customers to obtain information, communicate, register, open accounts, conduct banking transactions, and close accounts, including obtaining other information and transactions outside banking products, including financial advice (financial advisory), investment, financial-based transactions. Electronics (ecommerce) and different needs of bank customers.

\section{Conclusion}

Based on the analysis and discussion results, the authors conclude that the strategy to improve service quality through the digitalization of services at PT. Bank Negara Indonesia (Persero) Tbk. has been running well in terms of fulfilling services for increasingly digital customer needs. Meanwhile, the supporting factor in implementing a strategy to improve service quality through the digitalization of services is Bank Negara Indonesia's commitment to developing and increasing the digitalization of services to enhance the quality of service for increasingly digital customer needs. As for the inhibiting factors in implementing strategies to improve the quality of service through the digitalization of services at Bank Negara Indonesia, namely the lack of adaptation to the digital system is still challenging to eliminate conventional methods, BNI's internal work culture is not yet following the digitalization system and poor coordination between divisions in BNI. Digitizing services is a strategy to improve service quality at Bank Negara Indonesia; several things that need to be considered by Bank Negara Indonesia in improving service quality through the digitalization of services in the future are: (1) Improving work culture within BNI for changing conventional services to digitalized services so that BNI can continue to grow and develop in the era of digitalization. the competition is very fierce. (2) Enhancing the security system of a digitalized service to avoid possible risks such as cybercrime. (3) Opening up to changes that exist today so that they are not fixated on the old system by developing services towards digitalization. (4) Improved coordination between existing divisions at BNI to achieve better digitization BNI.

\section{References}

Al-Refaie, A. (2015). Effects of human resource management on hotel performance using structural equation modeling. Computers in Human Behavior, 43, 293-303. https://doi.org/10.1016/j.chb.2014.11.016

Avramidis, P., Asimakopoulos, I., Malliaropulos, D., \& Travlos, N. G. (2020). Do banks appraise internal capital markets during credit shocks? Evidence from the Greek crisis. Journal of Financial Intermediation, January, 100855. https://doi.org/10.1016/j.jfi.2020.100855

Bacile, T. J., Wolter, J. S., Allen, A. M., \& Xu, P. (2018). The Effects of Online Incivility and Consumer-toConsumer Interactional Justice on Complainants, Observers, and Service Providers During Social Media Service Recovery. Journal of Interactive Marketing, 44, 60-81. https://doi.org/https://doi.org/10.1016/j.intmar.2018.04.002

Bartnik, R., Wilhelm, M., \& Fujimoto, T. (2018). Introduction to innovation in the East Asian automotive industry: Exploring the interplay between product architectures, firm strategies, and national innovation systems. Technovation, 70-71, 1-6. https://doi.org/https://doi.org/10.1016/j.technovation.2018.04.002

Chamidah, N., Guntoro, B., \& Sulastri, E. (2020). Marketing Communication and Synergy of Pentahelix Strategy on 
Satisfaction and Sustainable Tourism. The Journal of Asian Finance, Economics and Business, 7(3), 177-190.

Dodds, W. B., Monroe, K. B., \& Grewal, D. (1991). Effects of Price, Brand, and Store Information on Buyers' Product Evaluations. Journal of Marketing Research. https://doi.org/10.1177/002224379102800305

Hassan, H. E., \& Wood, V. R. (2020). Does country culture influence consumers' perceptions toward mobile banking? A comparison between Egypt and the United States. Telematics and Informatics, 46(April 2019), 101312. https://doi.org/10.1016/j.tele.2019.101312

Kang, J. K., \& Shivdasani, A. (1995). Firm performance, corporate governance, and top executive turnover in Japan. Journal of Financial Economics, 38(1), 29-58. https://doi.org/10.1016/0304-405X(94)00807-D

Lo Liang kheng, et. a. (2010). The Impact of Service Quality on Customer Loyalty: A Study of Banks in Penang, Malaysia. International Journal of Marketing Studies, 2(2). www.ccsenet.org/ijms

Londhe, B. R. R. (2014). Marketing Mix for Next Generation Marketing. Procedia Economics and Finance, 11(1964), 335-340. https://doi.org/10.1016/S2212-5671(14)00201-9

Mashur, R., Gunawan, B. I., Ashoer, M., Hidayat, M., Perdana, H., \& Putra, K. (2019). Moving From Traditional to Society 5 . 0: Case study by Online Transportation Business. Journal Distribution Science, 9, 93-102. https://doi.org/http://dx.doi.org/10.15722/jds.17.09.201909.93

Nurhilalia, Rahman Kadir, A., Mahlia, M., Jusni, \& Aditya, H. P. K. P. (2019). Determinant of market orientation on SME performance: RBV and SCP perspective. In Journal of Distribution Science (Vol. 17, Issue 9, pp. 35-45). https://doi.org/10.15722/jds.17.09.201909.35

Peteraf, M. (1993). The cornerstones of competitive advantage: a resource - based view. Strategic Management Journal, 14(April 1992), 179-191. https://doi.org/10.1017/CBO9781107415324.004

Risal, T. (2019). Pengaruh Kualitas Pelayanan Terhadap Loyalitas Nasabah Dengan Kepuasan Sebagai Variabel Intervening Pada Bmt Kampoeng Syariah. JMB (Jurnal Manajemen Dan Bisnis), 1(1).

Sondakh, C. (2015). Kualitas Layanan, Citra Merek Dan Pengaruhnya Terhadap Kepuasan Nasabah Dan Loyalitas Nasabah Tabungan (Studi Pada Nasabah Taplus BNI Cabang Manado). Jurnal Riset Bisnis Dan Manajemen, $3(1), 19-32$.

Sung, E. (Christine). (2021). The effects of augmented reality mobile app advertising: Viral marketing via shared social experience. Journal of Business Research, 122(August 2020), 75-87. https://doi.org/10.1016/j.jbusres.2020.08.034

Suriyanti, S., Firman, A., Nurlina, N., Ilyas, G. B., \& Putra, A. H. P. K. (2020). Planning Strategy of Operation Business and Maintenance by Analytical Hierarchy Process and Strength, Weakness, Opportunity, and Threat Integration for Energy Sustainability. International Journal of Energy Economics and Policy, 10(4), 221-228.

Teece, D. J., Pisano, G., \& Shuen, A. (1997). Dynamic capabilities and strategic management. Strategic Management Journal. https://doi.org/10.1002/(SICI)1097-0266(199708)18:7<509::AID-SMJ882>3.0.CO;2-Z

Yoon C. Cho, E. S. (2015). Exploring Factors That Affect Usefulness, Ease Of Use, Trust, And Purchase Intention In The Online Environment. International Journal of Management \& Information Systems, 19(1), 21-56. 